\title{
Anglophone Marriage-Migrants in Southern Europe: A Study of Expat Nationalism and Integration Dynamics
}

\author{
Irina Isaakyan and Anna Triandafyllidou \\ European University Institute \\ Irina.Isaakyan@eui.eu \\ Anna.Triandafyllidou@eui.eu
}

\begin{abstract}
Today marriage-migration remains the dominant form of naturalization in Italy and Greece, even for women from such high-income countries as the USA. Pilot studies of intra-OECD female migrants to Southern Europe show that the majority of them marry local men, consider their matrimony a mistake and feel isolated. Unfortunately, there is no comprehensive knowledge about dynamics of their socio-cultural integration or expat nationalism (although scholarship generally acknowledges a strong relationship between these two processes).

Based on narrative-biographic interviews with sixty Anglophone female expatriates married to Italian and Greek men, our study explores the women's negotiation of culture within the context of their Italian and Greek families, and looks at emerging challenges for their integration. We show that these women are nationalistic and culturally-stringent actors, who often find it extremely difficult to fully learn and integrate to the new cultures of Southern Europe.
\end{abstract}

\section{Introduction}

Despite the feminization tendency, women-migrants often enter and settle in OECD countries through the traditional route of cross-border marriage (Kofman \& Meeto 2008; Lauth-Bacas 2010). However, the relationship between cross-border marriage and integration is not completely understood. Some view cross-border marriage as a direct outcome of integration while others recognize tensions that exist in mixed-nationality households (Charsely 2012; Constable 2005; Williams 2010). When the migrating woman marries the man from the host country, she is expected to become a part of his community, with her partner acting as a source of cross-cultural learning (Williams 2011). Albeit in practice, the integration-throughmarriage is not such a straightforward process.

While nuances of marriage-migrants' integration have been frequently addressed in relation to traditional - East-West or South-North - migrations, there is insufficient knowledge about cross-border marriage that fosters intra-OECD mobility. Within the mainstream of intraOECD migrations, the most interesting case is movement of Anglophone women to Southern Europe, whose fundamental patriarchies and kinship networks may clash with the western ideas of individualism and emancipation (Lauth-Bacas 2010; Trundle 2009).

According to Sriskandarajah and Drew (2006), there are around 300,000 US-national and UK-national women permanently living in Italy and Greece at the moment. The pilot studies conducted by Trundle (2009) and Lauth-Bacas (2010) respectively on Anglophone women in Florence and on German women in Athens show that the majority of these female migrants are married to local Italian and Greek men, consider their matrimony a mistake and feel 
culturally isolated. Unfortunately, there is little knowledge about the dynamics of their integration process

Although there are many works about the perception of immigrants' Otherness by the native majority (Alba \& Nee 2005; Constable 2005; Lauth-Bacas 2010; Palriwala \& Uberoi 2008; Trundle 2010), it remains obscure how the process of Othering may influence identity construction and consequently integration of the migrant in-group (Triandafyllidou 2001). The under-researched relationship between the Othering of the host and the redefinition of the migrant's own national identity becomes especially interesting when applied to the case of American (and other Anglophone) migrants. Their identities are marked by an escapist search for a better context of socialization, yet their identification with the American nation remains robust and they have a tendency to reject the input of the host culture (Benson 2011; Oldenburg 1989; Putnam 2000; Trundle 2009; Wennersten 2008).

In response to these shortages, we aim to study the dynamics of integration of Anglophone women in Italy and Greece within the context of cross-border marriage. We use the concepts of "national significant Other" and "banal nationalism" elaborated respectively by Gellner (1964) and Billig (1995) as heuristic devices to understand the challenges for integration caused by the cross-border marriage condition.

Two basic questions generate our study: How does the expat nationalism of Anglophone marriage-migrants in Italy/Greece work? To what extent does it interact with the integration processes of family dynamics, socialization practices and career development?

\section{Methodology}

This paper is part of a larger project about integration of women from Anglophone countries in Southern Europe, conducted under the auspices of the Marie Curie Intra-European Fellowship. The overall sample includes eighty women of the age between thirty-two and eighty who migrated to Italy or Greece between 1960 and 2008, all holding university degrees and relevant professional experience from their countries of origin. $75 \%$ of them (60 women) have been married to Italian/Greek men. Within the overall sample are also nine Anglophone family-migrants, nine single professional migrants and two solo-loving retired migrants. The informants were selected through the preliminary on-line survey and the snowballing strategy to address both the diversity and the frequency of integration factors, one of which is crossborder marriage.

Based on sixty in-depth interviews with US-national, British and Australian expatriatewomen who have been married to Italian and Greek men, the paper presented here explores their negotiation of culture within the context of their Italian/Greek families, where they reposition themselves against the hosts. [For basic socio-demographic information on these sixty women, see Appendix.]

The women were interviewed in September-December 2013 through the method of narrative interview face-to-face, by phone or Skype, with the average interview duration of two hours. For the purposes of confidentiality, the participants' real names are never mentioned. The interviews were analyzed through the methods of critical discourse analysis and narrativebiographic analysis. The latter lays a particular stress on turning points (the first encounter with the host culture or the encounter with the mother-in-law), epiphanies (about national repositioning) and narrative segments. ${ }^{1}$

${ }^{1}$ For more information on narrative-biographic analysis, see Creswell (2007). 


\section{Structure}

The paper is organized into two parts. In the first part we introduce the concepts of "banal nationalism", "national significant Other" and "cross-border marriage", which are further elaborated throughout the work. We highlight the epistemological inter-connection between the processes of national identification and cultural reification, and the phenomenon of expat nationalism with its specific focus on constructing the in-group. The cross-border marriage is viewed as a specific arena for expat banal nationalism for women.

In the second part of the paper we turn to our data and examine the interplay between the "ingroup" and the "Other" (specific persons involved in the family life, notably the husband and the mother-in-law). We highlight the national narratives of our interviewees, which take the form of negative expat nationalism and prevent their actual integration into the host society.

We argue that the informants' negative expat nationalism is related both to their specific (Anglophone) culture of origin and the way they understand themselves in the country of settlement (as "long term visitors" that have to evaluate the "inferior" culture of the country they are visiting). We coin the term "broken integration" to explain their difficulty to interact, adapt and eventually integrate within the host country's culture. This inability is viewed as part of the grand "love"- and "tourism" narratives that are prevalent in the Anglophone world, and that therefore foster Anglophone migrations to Southern Europe.

\section{National identity, Otherness and Cross-Border Marriage}

In migration studies, the themes of integration, national identity and culture are constantly interweaving. Integration is always challenging for nationalism as the former may disrupt the rhetoric of the latter. At the same time, both majority and minority nationalisms may support or impede the integration of immigrants (Alba \& Nee 2005; Segal 2010; Triandafyllidou 2001). Integration is thus largely shaped by nationalism, by how people understand their own national re-positioning towards one another. At the heart of national identification and readiness for integration is culture. The cultural component - with its emphasis on everyday, mass culture and cultural myths and traditions - is always the most difficult to negotiate and consequently to integrate.

In the opinion of Triandafyllidou (2001: 26), national identity conveys 'a double-edge relationship, which is inward-looking but also implying difference and presupposing the existence of Others'. Lamont and Molnar (2002: 167) note that construction of national identities creates 'symbolic boundaries for people or conceptual distinctions that separate people into groups and generate feeling of similarity and difference'. In many cases, these symbolic boundaries are drawn on the basis of culture rather than nationality. With its accent on common beliefs and behavioral conduct, culture 'reinforces national identity and forms an integral part of the distinction between Us and Them' (Triandafyllidou 2001: 25). The negotiation of symbolic boundaries between the immigrant and the host society lies at the heart of socio-cultural integration and constantly takes place in 'banal' or 'domestic' everyday contexts such as the pub, barbershop, salon or household (Billig 1995; Boym 2001; Mann 1988). In these settings, national identities and cultural hegemonies are reaffirmed through the habitual contact and discursive dialogue with the national significant others whose social roles are also marked by the presence of intimacy as a pre-requisite in such settings. Billig (1995), who has coined the term "banal nationalism", actually writes about the banal nationalism of the majority and only slightly mentions its link with their reproduction of 
Otherness. In this connection, very little is known about the expat banal nationalism or about the nation-building processes that take place in households.

As noted by Williams (2010: 54), 'Families are sites that establish and reaffirm the values of social groups; they are also sites in which the next generations are socialized into group norms, and marriage helps define who belongs and who does not'. Women's role in nationalism and diaspora formation is indeed no less than that of men because as housewives (mothers), women have more control over the reproduction of banal nationalism. Its items and cultural codes - such as domestic symbols, lullaby songs and nursery rhymes - and passed to younger generations through the mothers' hands (Constable 2005; Yuval-Davis 1998).

One such banal arena for national contestation is the cross-border marriage (Charsley 2012; Williams 2010; Yuval-Davis 1998), which is defined by Williams (2010) and Williams (2011) as the matrimony between the migrant and the host and in which the 'host partner' [in most cases, the man] and the 'imported partner' [typically the woman] learn to inhabit their new cultural condition (ibid). In our case, it is the marriage between one of our Anglophone female informants and an Italian or Greek man.

Motivation and preparedness for the cross-border marriage varies from culture to culture (Lauth-Bacas 2010; Palriwala \& Uberoi 2008; Williams 2011). A cross-border marriage may be strategic in some cases and irrational in others while female marriage-migrants may not always have the right knowledge about their destination countries and be unprepared for what they find on arrival (Constable 2005; Williams 2010: 70).

While the mismatch between expectations about and the reality of emigration has been frequently addressed in relation to traditional migrant-women, the cartographies of desire of non-traditional female migrants [who move from West to East or in-between OECD countries] remain under-researched. Moreover, it is unknown to what extent and in what ways the condition of the cross-border marriage may interact with migrant-women's expat nationalism and integration in host countries.

\section{Understanding expat nationalism: The 'national significant Others'}

Vickie (age 43) met her Italian husband in Washington DC in the mid 1990s, when they both were doctoral students. They married after the three months of dating. When their first child was born, they moved to Rome.

The basic thing that had made Vickie unhappy from the very beginning was her 'super-active mother-in-law', who keeps interfering into their lives all the time. Vickie 'hates' the situations when her mother-in-law tries to influence her children and to teach them certain - "Italian" ways of life such as dressing warmly for outside or wearing slippers in the house. In every situation, Vickie sees a cultural demise and a source of personal disempowerment. That is why she stresses militantly that she is the mother, who must hold the barricade against the nonn ${ }^{2}$, She consciously decided to remain the housewife 'in order to protect the children from the influence of their grandmother'. It was more important for Vickie to 'win the cultural battle' with her mother-in-law rather than to restore her own career of a medical researcher.

2 Italian for "grandmother". 
Disappointed by the host culture like Vickie, the majority of our cross-border-married informants think about their national significant others in rather negative terms most of the time. The phenomenon of "Othering" the native majority (Othering the host) has been frequently observed in migration studies, although without elaboration. Illuminated by our case, this type of Othering involves the informants' negative thinking about the Italian/Greek patriarchy and about the process of raising children in mixed-nationality families.

\section{The husband and his mother}

The Italian/Greek patriarchy has been viewed in the negative light because of unusual gender roles differentiation, in which women are placed on a lower level of the societal hierarchy and in which the supremacy of the man is supported by a variety of cultural codes and tools. For example, the overall organization of the Italian household routine is understood by the informants as very orthodox and uncivilized, when 'the women must do the household chores while the men can chat and relax':

Violet: ${ }^{3} \quad$ They have traditional roles for men and women. A woman should stay at home. She can only work if you need the money for the family. The woman's main job is the family here and to look after kids. It is not really what I am used to.

A particular theme that emerges from these narratives is the 'Italian/Greek mother-in-law, without which an understanding of the female migrant's experience would be incomplete', in the opinion of Vickie and many others. For the majority of our informants it is a very challenging issue. ${ }^{4}$ It was especially challenging for those women who for whatever reason could work and wanted to restore their power and self-esteem within their families as wives and mothers.

All acknowledge that their mother-in-law did interfere into their household on a regular basis and their relationship with their husbands. For example, the mother-in-law can enter the house whenever she wants and completely re-arrange the furniture. This is what happened to Vickie when she was in hospital for two weeks. 'She was literally sleeping between us in our bed' says Miranda, bursting into tears: ${ }^{5}$

First, she would come to our bedroom late at night when we were already going to bed, and would say that she was feeling insomniac and lonely and would like to watch TV with us for a little bit. She would nest herself comfortably into our bed and soon pretend to be sleeping. This is how we were spending our nights for some time.

The mother-in-law could interfere into how the informant was bringing up her children. In particular, the mother-in-law would advise them on what they should wear and what language should be spoken at home vis-à-vis the informant's position. This interference could be at times very obtrusive and in the presence of the informant's children. The mother-in-law could also set her son against his wife. In some cases, the mother-in-law became the main

${ }^{3}$ Violet (age 38) is an Australian medical researcher now living in Sicily.

${ }^{4}$ See also Lauthas-Bacas (2010), who studies the cross-border marriage between German women and Greek men.

${ }^{5}$ Miranda (age 45) is a former business executive from South Africa, who migrated to Greece in 1995. She was married to a Greek man for nine years. Divorced, she now lives in Athens as a housewife and raises her two children. 
contributor to the divorce or deterioration of marital relations and the spouses' alienation from each other.

In many cases, the Italian/Greek husband was supportive of his mother to the detriment of his wife's wellbeing. My Italy-based informants and the work of Trundle (2009) conceptualize this behaviour as the 'mammone'-type of husband - or the "mommy's boy" - which, as Maya ${ }^{6}$ notes, is 'quite a shameful experience for American guys but an absolute norm for Italian men'. When Miranda from Athens was, at one point, choosing an elementary school for her child, her Greek husband said, "My mother and I have decided that our kid should go to this particular school!" Miranda admits that exclusively because of the regularity of such positioning and antitheses, her marriage had eventually ended up in a divorce.

Williams (2010) notes that in cross-marriage narratives of women-migrants across national contexts, the host-husband is usually as a 'silent' and 'mysterious' figure, which is also true for our informants. Many of them find it extremely difficult to interpret their husbands' positioning in relation to what is going on in their households. In the opinion of Ronda (one of our informants and a qualified US-national psychiatrist from Naples who consults Anglophone women married to Italian men), many Anglophone wives fall into an easy trap of conceptualizing their Italian husbands as "mammone" and thus falsely reproduce the matriarchy discourse, which 'leads them even further away from a real understanding of who their significant others actually are'. Ronda stresses that the Italian husband is the pivotal although "behind-the-scenes" - actor; which resonates with the understanding of Greek husbands by Monica (another psychiatrist from Athens):

Ronda: All cases of involving the mother take place when the wife is not ready to negotiate with her husband the cultural terms of his country. If his mother comes to their house, it means that he has asked her to do this. And usually the husband asks his mother to help his wife to learn because he does not want to be arguing over this with a woman too much. This is another part of the Italian masculinity, another stereotype about the man who should not be combatting with a woman over their daily routine. This contradicts the Italian idea of masculinity.

Based on many years of clinical work with Anglophone women in Southern Europe, both Ronda and Monica argue that the husband's mother is a very strong cultural symbol, which protects the patriarchal motives of her son or the male-dominated patriarchy. 'She is the mother of the patriarch, his second ego', notes Ronda. She further explains that it is not the mother who dictates the son what to do with his wife - it is the son who wants his mother to support his male decisions because he thinks that it is 'not the man's job to argue with the woman whereas there is another woman (his mother) to bring home certain ideas to his wife'.

\section{The children: The 'national Others' or allies?}

A cross-cultural conflict that the informants find extremely difficult to negotiate with their Italian or Greek in-laws is the question of how to raise the children in those mixed-nationality families. Bringing up the children in such culturally divided households is being constantly subjected to the pressure of the "Italian" or "Greek" dress-code and other cultural codes, protected by the mother-in-law. Thus while the informant wants her children to be lightly

\footnotetext{
${ }^{6}$ Maya (age 51) is a former actress from New York who now lives in Florence. At the
} moment, she is undergoing the divorce process. 
dressed in summer or to walk bear-foot on the carpet, her in-laws insist on the kids wearing shoes and warm clothes, which is seen by the informants in the negative light:

Vickie: In America the most typical things are to dress lighter in cooler weather and to wear foot-flops in spring, and no shoes or socks on the floor. In Italian culture you don't wear bare feet on the floor. You wear slippers even on the carpet. In the house they put foot-flops or slippers or at least thick socks with suction over tops of their socks. Even in the summer time they have the summertime slippers. My kids never do. But if they are in the house of the nonna you can always hear her saying, "You gotta put socks or slippers on your feet! You gotta wear jacket", even if they feel hot. You should see Italian kids in the wintertime - completely covered from head to toes, like the Arctic penguins.

Violet: In my opinion, it is a hot day and you should let your kids wear whatever clothes they are comfortable with. But here in Sicily, they dress up their kids warmly and do not let them play because they believe that the kids will sweat and get sick.

The informants also have quite militant reactions to their sons becoming 'feminized by the soft Italian culture' or 'spoilt by the child-centred Greek culture', in which they are encouraged by their grandmothers not to clean after themselves, not to cook or not to wear heavy backpacks to school - and therefore to 'get stuck on the child-level of development'. 'Here in Greece, a guy is made to remain a child for a long time, even when he is already in his early thirties - which is not appropriate for America', notes Georgia. Such feminization clashes with the American idea of scout-education and with the American "frontier" myth (see Smith 2013: 55).

The children thus become a Janus-faced product of cross-border marriage as they may easily turn into another "national Other", bonding with the father or mother-in-law, which often happens:

Darlene: ${ }^{7}$ My son is in his late twenties, and he is very much like his father - a very typical "Italian man", with a kind of stubborn mentality. He used to have American girl-friends. But it did not work. He is now engaged to a Sicilian girl, with whom he feels very comfortable because she has very traditional ways of behaving and arranging the house. He was very close with my late husband and his mother. Without any doubt, they had impacted a lot.

Brook: ${ }^{8}$ My kids have developed a very close relationship with their grandmother (my mother-in-law). They now look at the world through her eyes, which is very difficult for me to deal with.

At the same time, the children are viewed as possible allies for the Anglophone mother, who tries to cut off their cultural bonds with her mother-in-law.

Vickie: I am fighting for my kids. I always engage them in various camping activities, like in the US. I don' want them to be like her. They are my kids.

\footnotetext{
${ }^{7}$ Darlene (age 70) is an artist from London, who now lives in Milan.

${ }^{8}$ Brook (age 49) is from the South of England. She lives in Athens.
} 
Ronda: Because these two women [the American wife and her mother-in-law] spend most of their time together so far, it is easier for the wife sometimes to manipulate the situation. This is where women obtain their power - in their households. That is why many Anglophone women prefer to stay at home and try to speak more English to their kids. This preserves the cultural symbolism of the Anglophone world.

Ronda believes and our findings also show that Anglophone women often use their children as a specific tool to restore their cultural hegemony within their households - the 'kitchensink royalty'. Our interviewees thus often reach the decision either to interrupt or not to resume their previously successful careers of the lawyer or business executive, and reconcile themselves with the "housewife" stigma in order to stay at home with their children and to help them learn the native English and American or Anglophone culture.

Ronda and Monica admit that it is difficult and time-consuming to work with 'those militant nationalists' and 'to break through their false perceptions' of their significant national others. Informants are aware that their choices are suboptimal as they are frustrated by not resuming their careers and the kids miss out on their grandparents, but transmitting to the children their own culture and identity eventually overrides these concerns. As Vickie confesses, 'It might have been better for the kids to spend more time with their nonna and to be kind of spoilt by her. I would also have better chances to restore my own career. But it is important for me to help them remain American. This is my identity.'

In terms of family dynamics, some of the cross-border married couples end up in a divorce. The majority stay together, although their marital relations may remain very tense for a long time. The decision not to divorce was made as a result of the women's fear of 'stepping into nowhere' and of separating from their children if they would move back to the USA or UK. Brook's reflections on her marriage below resonate with those of many others:

I always wanted a divorce. Amazingly, I never asked for it and we never discussed it. I think I always knew that I would not manage it. I would not be able to bring my kids to the UK with me without his permission, which he would never give me. And if I would meet someone - a UK or US guy - I would not be able to live with him in the UK or the US. Why would I need it then at all? Above that, it was not very pleasant to be a divorced woman in Greece. It is already a stigma to be a migrant - so "divorcee" would be the double-stigma.

Many informants feel the same. However, ashamed of their loss of power, they often explain the decision to stay together in terms of love: 'Why did I decide not to divorce him? Well, the children first of all. Also love, I guess. We were in love once, and now I cannot betray my heart'.

\section{Integration dynamics: Eternal tourists?}

Our interviewees admit that they have married their husbands for the irrational reason of love. Giddens (1992) and Williams (2010) point to the western nostalgia for romantic love as a response to the over-modernization and materialism of today's world. The romantic life-style narrative fosters various forms of tourism, with emphasis on breaking from daily life to experience a change (Lanfant 1993; Stronza 2001). 
As socio-cultural conditions of modernity, the touristic self-quest and love-search interweave into the discursive idea of travelling with love in mind. By the time of meeting their Italian and Greek husbands, our informants were either 'very lonely' or 'bored with dating familiar American guys'. The interviewees needed 'a glimpse of something fresh and extraordinary, a spark of a new life, something exciting and unforgettable in the cold and well-calculated American culture'. Regardless of how successful her cross-border marriage is, each informant recalls with affection her first encounter with the husband-to-be. Associated with sensual love, the Italian or Greek man was offering something that her prior boyfriends did not have:

Gemma: I was thirty-two and at the point in my life where I thought I would never get married. I had given up on men and had decided not to take them too seriously anymore and just to focus on my career. I was returning on from a business meeting in Atlanta back to Miami. In the plane, I was walking down the aisle, looking ahead for my seat. Above the seat, I saw a male face and he looked right at me and mouthed the word 'wow'. I smiled because I thought it was so cute how forward he was. When I went to sit down, his seat was directly behind mine so I looked at him and said 'hi'. We talked the whole flight. We went out on a date the following night and then ended up spending the entire weekend together. From there our love began.

Naomi $^{9}$ (a former professional tennis player from the US) met her Greek husband in a disco club. Like with Gemma, his unusual behavior had immediately aroused Naomi's interest in a possible relationship:

Naomi: I came to Greece, basically following my heart. I had fallen in love with a hot Greek guy whom I met in the US. I was with my sister at disco when she said: "Look at that handsome guy!" I made a joke: "By the end of the night, he will be talking to the sky". I suddenly heard a voice behind me in the broken English, asking me why I wanted to give all the men there such a hard time. I turned around, and it was him. He grabbed me and kissed me. That was the way he took my heart.

According to the laws of tourism, the romantic dating lasted from two weeks to a couple of months until the couple either married or moved in together. Some of them made romantic tours to Europe, on which they met their husbands. Others engaged in alternative forms of tourism such as an exchange year in Italy. For example, Darlene was a UK student and an aspiring artist in the 1960s when she came to Sicily in search of 'inspiring landscapes and the perfect light'. Even when the informant's future husband would come to the US, her new experience was akin to a voyage to a new culture.

Scholars warn that the media-scapes of romantic tourism often shape false stereotypes (Rossel 1988; Stronza 2001; Urry 1990). Since tourism is 'a recognized industry' (Stronza 2001), engaging Anglophone expatriates; they themselves send back the "tourist-gaze" remittances. This includes bestsellers by Gilbert (2006) and Mayes (1996), which propagate certain mythic features of the Mediterranean culture while the authors' experiences of broken integration are overshadowed. Our informant Brenda, who is writing a novel about her own experience in Tuscany, says: 'There is no truth in the book Under the Tuscan Sun or in the movie Letters to Juliette. Eternal sunshine, eternal love and Franko Nero on a horse - nothing like that exists in real life. This is how naïve American girls longing for love and change are misinformed'.

${ }^{9}$ Naomi (age 50) is now remarried to a British man, living in Greece. 
The informants confess that at the time of their entry to Italy or Greece, they in fact knew almost nothing about the real Italian or Greek culture.

Our interviewees were indeed dreaming of another modality, which would be more orthodox in its historical richness. They expected this modernity to be "given" rather than demanding their own effort. In this connection, Urry (1990) notes on 'the tourist gaze' as a pervasive habit of having 'the upper hand' with another culture. The complexity is added by specific US-national myths that underpin identities of Americans from birth.

One such is the myth of 'the lone individual pushing America's frontier ever outward' (Smith 2013: 55). 'This is what Americans are taught from childhood', notes Ronda in her synthesis of the "frontier-" and "tourist-gaze" myths, "Whatever happens stay who you are. When an American woman meets an Italian guy during a romantic trip, she expects him - but not herself'.

Another myth that generates our informants' expat nationalism is the idea of 'America's worldly mission to bring liberty to the world' (ibid). The missionary philosophy affects their understanding of how cross-border marriage should work. As further elaborated by Ronda, 'The American woman is sure that everyone will love her for just being American. She is sure that she has come to save Italy from parochialism'.

In this complex tapestry of the national myth and global "life-style"-narrative, there shapes one's inability to integrate. ${ }^{10}$ As Ronda concludes on the cultural arrogance of her clients:

The major problem they face is that American people find it very difficult to recognize the existence of cultural diversity. They find it hard to see that there are multiple cultural realities, each having the right for its own existence; and that America - or the Anglophone world - is not the centre of the universe.

\section{What happens to integration?}

As a way of making choices rather than just thinking, expat nationalism invariably affects integration processes such as family dynamics, socialization within a local community, child education. Our findings show that the negative evaluation of the native majority located within the cross-border marriage has made an adverse effect on the informants' socioeconomic integration and general wellbeing. First, it negatively impacts upon their career development since many informants have preferred to stay at home and to fight their national others over their children's cultural re-positioning.

Second, the negative Othering of the native majority adversely impacts upon the informants' health and wellbeing. For example, Vickie refused to go to hospital for a routine examination because she did not want to 're-condition her children after the mother-in-law', while Violet (who was eight-month pregnant) had nearly lost her child because she 'had decided not to ask the mother-in-law for help whatever would happen'.

${ }^{10}$ Studies on traditional migrants show that the comparative strength of women's rights in the host and origin countries can also affect integration, with it being easier in a country with a tradition of greater gender equality than less. See Constable (2005), and also Palriwala and Uberoi (2008). 
Another effect of the informants' expat nationalism on integration is the in-group differences caused by the former - for example, between Anglophone women married to Italian/Greek men and Anglophone women married to Anglophone men (family-migrants) or unmarried professional women. The cross-border marriage and the presence of the national significant others intensify the conflict. ${ }^{11}$ For example, for Anglophone migrant couples - such as Kendra and her husband or Sally and her husband ${ }^{12}$ - who raise kids in Italy it is not a critical issue which language is spoken to the child at home. Both Sally and Kendra welcome any opportunity of introducing their children to the Italian language. Thus Sally (who does not have to work as her husband is very rich) hires an Italian baby-sitter.

Of course, our informants who are not involved in cross-border marriages also make negative judgments about the host culture from time to time. However, their integration is not seriously affected by such negative assessments. The intensity of their negative thinking about the host culture is thus very different. Here we can speak about two kinds of Othering the native majority: (1) fragmented Othering; and (2) total Othering. In the case of fragmented Othering, the women (who are not cross-border migrants) mostly focus on positive things while assessing the host country, which is equivalent to the cliché "The glass is still half-full". The final statement about liking or disliking Italy or Greece is ambivalent rather than negative, with no actual or even implicated desire to return.

On the contrary, the total (or judgmental) Othering (specifically observed among many of our cross-border migrants) leads to the categorical final statement that the Other is "really bad" [e.g.: "The glass is already half-empty"]. Thus the woman may say, 'I don't like anything at all about Italy/Greece except a couple of things...' and name ten or twelve positive attributes - instead of saying, 'I like many things about Italy/Greece except a couple of minor things that sometimes bother me'. Such negative evaluation is based on discursive misrepresentation or discursive reduction of the host country's positive features, and is supplemented by an actual - although impeded - desire to return.

Our research shows that in the cross-border marriage, the banal role of expat nationalism ${ }^{13}$ makes certain disputes quite tangible as nationalistically coloured. For example, such a banal cultural item as the manner of dressing or raising one's children may become a symbol of and a powerful device for the informants' everyday nationalism. In the intensity of their expat nationalism, our informants who fall into the category of the "cross-border marriage migrant" are also quite distinguishable from other types of the family migrant [e.g.: migrating couples of the same nationality].

Although attracted from the outside by certain aspects of the Mediterranean culture, many Anglophone marriage-immigrants remain unprepared for encounters with the associated patriarchy. Such readiness is especially difficult for US-national women to attain because they have an expectation of a certain prevalence of their own culture in the host nation. The tourist-like mentality and the overall context of one's inability to learn a new culture generate banal expat nationalism among marriage-immigrants in the form of their Othering of the host.

${ }^{11}$ Although women often have disagreements with their husbands and/or mothers-in-law from the same country of origin, this - unlike in a cross-border marriage - does not lead them to pronounce that their in-laws are a different national culture. See Pyke (2000).

${ }^{12}$ Sally (age 38) is a British designer from Oxford and her husband is a lawyer commuting between London and Florence. Kendra (age 41) is a former teacher, who now lives with her husband in the South of Italy and run the family business of wine-making.

${ }^{13}$ Paraphrasing Billig's (1995) banal nationalism we refer here to the banal form of expat nationalism which is enacted in everyday life by our informants. 
Our work elaborates on the reversion of negative Othering as part of the Anglophone expat nationalism in Southern Europe and shows that the respondents militantly perceive the native majority as the Negative Other. Moreover, the high level of intimacy (bordering with intrusion into privacy) and everyday (patriarchal) values of the mass/public culture foster the Anglophone women to reject this culture as undesirable because these cultural elements are contradictory to their national conception of gender equality and power as well as to their idea of modernization. While re-positioning themselves insofar, the informants display a very static view of culture, and see their significant national Others as paranoid, physically weak and ill-mannered - that is, "under-developed" both physically and mentally.

In response to the Italian/Greek patriarchy, the informants' expat nationalism is also highly gendered since their experience of being a woman is stretched to the extreme and their Othering of the host is grounded in their emphasized femininity. In support of the hegemonic masculinity of her son, the Italian/Greek mother-in-law emphasizes her femininity as the mother who wants to protect the traditional family of her son, to which the Anglophone wife reacts with her emphasized femininity of the mother who wants to liberate her family from southern European patriarchy.

Scholars often argue that banal nationalism and expat nationalism are in most cases irrational by their nature, and it may at first sight appear that our informants cease to be pragmatic actors as soon as they engage in their emigration projects. They do, in fact, enter Italy or Greece on absolutely irrational grounds, under the impact of the romantic lifestyle-narrative, which reassures them to wait for the "Mediterranean Prince Charming" yet always remain on the "American mission". Then they use the economic discourse to justify their irrational decisions to stay at home and to protect their national culture. However, later they use the irrational "love"-discourse to justify their rational choices not to separate from the (abusive) husband.

Within this complex and nationalistically tinted interplay of irrationality and rationalism that underpin their lifestyle choices, the process of our interviewees' integration is at best fragile (between unhappy family life and interrupted career) and at worse broken (as they remain tied to their expat nationalism but belong neither here nor there).

\section{References}

Alba, R. and V. Nee. (2005). Remaking of the American Mainstream. Harvard, MA: Harvard University Press.

Alexandrova, N. (2007). 'The topos of love in the life-stories of migrant women', in L. Passerini et al. (Eds.) Women Migrants from East to West: Gender, Mobility and Belonging in Contemporary Europe. Oxford and New York: Berghahn Books.

Billig, M. (1995). Banal Nationalism. London: Sage.

Block, A. (2011). 'Intimate circuits: Modernity, migration and marriage among post-Soviet women in Turkey', Global Networks 11(4): 502-21.

Boym, S. (2001). The Future of Nostalgia. New York, New York: Basic Books. 
Charsely, K. (2012). 'Transnational marriage', in K. Charsely (Ed.) Transnational Marriage: New Perspective from Europe and Beyond. New York/London: Routledge. Pp. 3-22.

Constable, N. (2005). Cross-Border Marriages: Gender and Mobility in Transnational Asia. Philadelphia, PA: University of Pennsylvania Press.

Creswell, J. (2007). Qualitative Inquiry and Research Design: Choosing Among Five Approaches. London: Sage.

Deutsch, K. (1966). Nationalism and Social Communication. Cambridge MA: The MIT press.

Gellner, E. (1964). Thought and Change. London: Weidenfeld \& Nicholson.

Giddens, A. (1992). Modernity and Self-Identity. Cambridge, UK: Polity.

Gilbert, E. (2006). Eat, Pray and Love. London: Penguin Books.

Kofman, E. and V. Meeto (2008). 'Family Migration', in World Migration 2008. Geneva: International organization for Migration.

Lamont, M. and V. Molnar. (2002). 'The Study of boundaries in the social sciences', Annual Review of Sociology 28: 167-195.

Lanfant, M. (1993). 'Methodological and conceptual issues raised by the study of international tourism', in Tourism Research: Critiques and Challenges. D. G. Pearce \& R. W. Butler (Eds.) Pp. 70-87. London: Routledge.

Lauth-Bacas, J. (2010). 'Cross-border marriages and the formation of transnational families: A case study of Greek-German couples in Athens', Transnational Communities Programme Working Papers. Retrieved 25 January 2014, from: http://www.transcomm.ox.ac.uk/working\%20papers/WPTC-02-10\%20Bacas.pdf.

Mann, M. (1988). States, War and Capitalism. Oxford: Blackwell.

Mayes, F. (1996). Under the Tuscan Sun. New York: Broadway Books.

Oldenburg, R. (1989). The Great Good Place. New York: Paragon House.

Palriwala, R. and P. Uberoi. (2008). Marriage, Migration and Gender. Thousand Oaks, CA: Sage.

Pyke, K. (2000). 'The normal American family', Journal of Marriage and Family 62: 240255.

Putnam, R. (2000). Bowling Alone: The Collapse and Revival of American Community. New York/London: Simon \& Schuster.

Rossel, P. (1988). Tourism: Manufacturing the Exotic. Copenhagen: IWGIA.

Segal, U. (2010). 'The immigration process', in U. Segal et al. (Eds.) Immigration Worldwide. Oxford University Press. 3-16.

Shils, E. (1995). 'Nation, nationality, nationalism and civil society', Nations and Nationalism 
1: $95-118$.

Smith, T. (2013). Time No Longer. New Haven \& London: Yale University Press.

Sriskandarajah, D. and C. Drew (2006). Brits Abroad: Mapping the Scale and Nature of British Emigration. Retrieved 1 July 2011, from: www.ippr.org/publicationsandreports.

Stronza, A. (2001). 'Anthropology of tourism', Annual Review of Anthropology 30: 261-283.

Triandafyllidou, A. (2001). Immigrants and National Identity in Europe. London: Routledge.

Trundle, K. (2009). 'Romance tourists, foreign wives, or retired migrants?', in O'Reilly and M. Benson (Eds.) Lifestyle Migration. Farnham: Ashgate. Pp. 51-68.

Urry, J. (1990). The Tourist Gaze. London: Sage.

Wennersten, J. (2008). Leaving America: The New Expatriate Generation. Santa Barbara, CA: Praeger Publishers.

Williams, L. (2010). Global Marriage: Cross-Border Marriage Migration in Global Context. Basingstoke, UK: Palgrave Macmillan.

Williams, W. (2011). The Globalization of Love. Summertime Publishing.

Yuval-Davis, N. (1998). Gender and Nation. Thousand Oaks, CA: Sage. 